\title{
Factors associated with age at slaughter and carcass weight, price, and value of dairy cull cows
}

\author{
I. Bazzoli, ${ }^{*}$ M. De Marchi, ${ }^{\star 1}$ A. Cecchinato, ${ }^{\star}$ D. P. Berry, $†$ and G. Bittante ${ }^{\star}$ \\ *Department of Agronomy, Food, Natural Resources, Animals, and Environment (DAFNAE), University of Padova, Viale dell'Università 16, \\ 35020 Legnaro (PD), Italy \\ †Animal and Grassland Research and Innovation Centre, Teagasc, Moorepark, Co. Cork, Ireland
}

\begin{abstract}
The sale of cull cows contributes to the overall profit of dairy herds. The objective of this study was to quantify the factors associated with slaughter age (mo), cow carcass weight $(\mathrm{kg})$, price $(€ / \mathrm{kg}$ of carcass weight), and value $(€ /$ head) of dairy cull cows. Data included 20,995 slaughter records in the period from 2003 to 2011 of 5 different breeds: 2 dairy [Holstein Friesian (HF) and Brown Swiss (BS)] and 3 dual-purpose [Simmental (Si), Alpine Grey (AG), and Rendena (Re)]. Associations of breed, age of cow (except when the dependent variable was slaughter age), and year and month of slaughter with slaughter age, carcass weight, price, and value were quantified using a mixed linear model; herd was included as a random effect. The seasonal trends in cow price and value traits were inversely related to the number of cows slaughtered, whereas annual variation in external factors affected market conditions. Relative to BS cows, HF cows were younger at slaughter (73.1 vs. $80.7 \mathrm{mo}$ ), yielded slightly lighter carcasses (242 vs. $246 \mathrm{~kg}$ ), and received a slightly lower price (1.69 vs. $1.73 € / \mathrm{kg}$ ) and total value (394 vs. $417 € /$ head). Dualpurpose breeds were older and heavier and received a much greater price and total value at slaughter (521, 516 , and $549 € /$ head, respectively for $\mathrm{Si}, \mathrm{Re}$, and $\mathrm{AG}$ ) than either dairy breed. Of the dual-purpose cows, Si carcasses were heavier $(271 \mathrm{~kg})$, whereas the carcasses of local breeds received a higher price (2.05 and 2.18 $€ / \mathrm{kg}$ for Re and AG, respectively) and Alpine Grey cows were the oldest at slaughter $(93.3 \mathrm{mo})$. The price per kilogram of cull cow carcasses was greatest for very young cows (i.e., $<3$ yr of age) and the differential in price and value between younger and older cows was greater in dual-purpose than in dairy breeds. Large differences in cull cow whole carcass value (carcass weight $\times$ unit price) among dairy breeds suggest that such a trait could be considered in the breeding objectives of the breeds.
\end{abstract}

Received January 15, 2013.

Accepted October 13, 2013

${ }^{1}$ Corresponding author: massimo.demarchi@unipd.it
Key words: cull cow, carcass price, carcass value, age at culling

\section{INTRODUCTION}

The sale of cull cows represents a revenue source for dairy farms. Beef originating from culled dairy cows accounts for approximately $13 \%$ of domestically produced beef in the United States (USDA, 2005). Similarly, cull cows can represent 10 to $15 \%$ of the revenues of dairy farms in most European countries (Cabaraux et al., 2005); meat originating from cull cows can represent most of the beef consumed in some countries (Liboriussen, 1980; Vestergaard et al., 2007).

Factors influencing the decision to cull dairy cows include reproductive failure, mastitis and udder problems, low milk production, and old age. Several studies (Beaudeau et al., 1993; Esslemont and Kossaibati, 1997; Bascom and Young, 1998) have documented reproductive failure as the primary reason for culling, accounting for approximately $23 \%$ of culling events (Allaire et al., 1976). Mastitis and udder problems were identified as the second most important reason for culling (Bascom and Young, 1998; Smith et al., 2000; Cesarini et al., 2003), accounting for approximately $16 \%$ of culling decisions.

Breed of cow has been reported to influence culling rate (Heikkilä et al., 2012) but has also been documented to influence carcass weight and the value of cull cows (De Boer, 1980; Wiemer et al., 1982) as well as meat quality characteristics of beef cows (Dransfield et al., 2003). Several studies have quantified the effect of plane of nutrition on slaughter and meat traits, particularly in beef cull cows. Vestergaard et al. (2007) and Schnell et al. (1997) both reported clear differences in carcass characteristics of cull cows fed different diets. Increasing the nutritional plane of cull cows through supplementation before slaughter improved carcass characteristics (Matulis et al., 1987; Brown and Johnson, 1991; Minchin et al., 2009), as well as conformation and carcass fat level (Apple, 1999) and tenderness of meat (Miller et al., 1987). 
Furthermore, several studies have documented an effect of age at slaughter on carcass traits of dairy and beef cull cows (van Arendonk et al., 1984; Seegers et al., 1998) and also on BCS and carcass conformation (Vestergaard et al., 2007). The majority of studies on culled dairy cows were, however, undertaken under intensive production conditions or on extensive pasture environments, and there remains a paucity of knowledge of such in mountainous dairy production systems.

The aim of this study was to investigate the association between cow breed and year and month of slaughtering with age at slaughter, carcass weight, price, and value in culled dairy and dual-purpose cows reared in Alpine conditions.

\section{MATERIALS AND METHODS}

Animal care and use committee approval was not obtained for the present study because all of the data originated from a preexisting database from the Breeders Federation of the Trento Province (Trento, Italy) and the Unipeg Cooperative of Pegognaga (Mantova, Italy).

\section{Data}

Slaughter records on 20,995 cull cows of 5 breeds [2 dairy: Holstein Friesian (HF) and Brown Swiss (BS) and 3 dual-purpose: Simmental (Si), Rendena (Re), and Alpine Grey (AG)] originating from 486 dairy herds, between the years 2003 and 2011, were provided by the Breeders Federation of Trento (Trento, Italy), located in northern Italy. Crossbred cows were not included in the analysis due to a paucity of data. The farming systems of the area were described in detail by Sturaro et al. (2009, 2013). Cull cows were collected from dairy farms each Wednesday by the Breeders Federation and transported to a commercial slaughterhouse (Unipeg, Pegognaga, Italy) on Thursday. Information available on each animal included herd, breed, birth date, slaughter date, carcass weight $(\mathrm{kg})$, and carcass value $(€)$. Age at slaughter (mo) and carcass price $(€ /$ $\mathrm{kg}$ ) were computed.

After examination of the distribution of the data available, only purebred dairy and dual-purpose cows between 24 and 200 mo of age at slaughter, a carcass weight between 170 and $400 \mathrm{~kg}$, and a carcass value between $€ 200$ and $€ 1,200$ were retained. Furthermore, only animals from herds that supplied at least 10 cull cows across the whole study period were retained. In total, 6,931 records were discarded during the editing process; 8,927 HF, 9,555 BS, 1,117 Si, $917 \mathrm{Re}$, and 479 AG cull cows remained after editing. In $25.5 \%$ of the herds only 1 breed of cow was represented, whereas in $39.3 \%$ and $28.0 \%$ of the herds, 2 and 3 breeds were represented, respectively.

\section{Statistical Analysis}

Factors associated with age at slaughter (mo), carcass weight $(\mathrm{kg})$, carcass price $(€ / \mathrm{kg})$, and carcass value $(€)$ of cull cows were quantified using REML in a linear mixed model framework in PROC MIXED (SAS Institute, 2008). The significance of fixed effects in the model was based on the F-statistic and the significance of the random effects in accounting for the variation in the dependent variable was determined using the Akaike's information criterion (AIC; Akaike, 1969; Agresti, 2002) between models. The lower the AIC, the more parsimonious the model. The AIC includes a penalty for over-parameterization, to obtain a balance between fit and number of parameters to be estimated, and was calculated as follows:

$$
\mathrm{AIC}=-2 \times \log \mathrm{L}-2 \times(\mathrm{k}+\mathrm{s}),
$$

where $\mathrm{k}$ represents the number of response levels minus 1 , and $\mathrm{s}$ is the number of predictive effects.

In all models, the random terms of herd and residuals were assumed to be independently and normally distributed with a mean of zero and variance of $\sigma_{H}^{2}$ and $\sigma_{e}^{2}$, respectively. The general model fitted (based on biological plausibility) was:

$$
\begin{aligned}
& \mathrm{y}_{\mathrm{ijklm}}=\mu+ \mathrm{H}_{\mathrm{i}}+\mathrm{B}_{\mathrm{j}}+\mathrm{YS}_{\mathrm{k}}+\mathrm{MS}_{1}+\mathrm{A}_{\mathrm{m}}+\mathrm{bCW} \\
&+(\mathrm{B} \times \mathrm{A})_{\mathrm{jm}}+(\mathrm{B} \times \mathrm{YS})_{\mathrm{jk}}+(\mathrm{B} \times \mathrm{MS})_{\mathrm{jl}} \\
&+(\mathrm{YS} \times \mathrm{MS})_{\mathrm{kl}}+\mathrm{e}_{\mathrm{ijklmn}},
\end{aligned}
$$

where $y_{\mathrm{ijklm}}$ is the observed trait; $\mu$ is the overall intercept of the model; $\mathrm{H}_{\mathrm{i}}$ is the random effect of the ith herd $(i=1, \ldots, 486) ; B_{j}$ is the fixed effect of the jth breed $(j=H F, B S, S i, R e, A G) ; Y_{k}$ is the fixed effect of the kth year of slaughter $(\mathrm{k}=2003, \ldots, 2011) ; \mathrm{MS}_{1}$ is the fixed effect of the lth month of slaughter $(l=1$, $\ldots, 12) ; A_{m}$ is the fixed effect of the mth class of age of cull cow $(\mathrm{m}=1=<3$ yr of age; $2=$ between 3 and $4 \mathrm{yr} ; 4=$ between 4 and $5 \mathrm{yr} ; 5=$ between 5 and $6 \mathrm{yr}$; $6=$ between 6 and $7 \mathrm{yr} ; 7=>7 \mathrm{yr})$; $\mathrm{CW}$ is the linear covariate of carcass weight; $(\mathrm{B} \times \mathrm{A})_{\mathrm{jm}}$ is the interaction effect between breed and age of cows at slaughter; (B $\times \mathrm{YS})_{\mathrm{jk}}$ is the interaction effect between breed and the year of slaughter; $(B \times M S)_{j 1}$ is the interaction effect between breed and month of slaughter; $(\mathrm{YS} \times \mathrm{MS})_{\mathrm{kl}}$ is the interaction between the year and month of slaughter; and $\mathrm{e}_{\mathrm{ijklmn}}$ is a random residual.

This model was used to analyze carcass price data $(€ / \mathrm{kg})$. Carcass weight $(\mathrm{kg})$ and carcass value $(€ /$ head $)$ 
1084
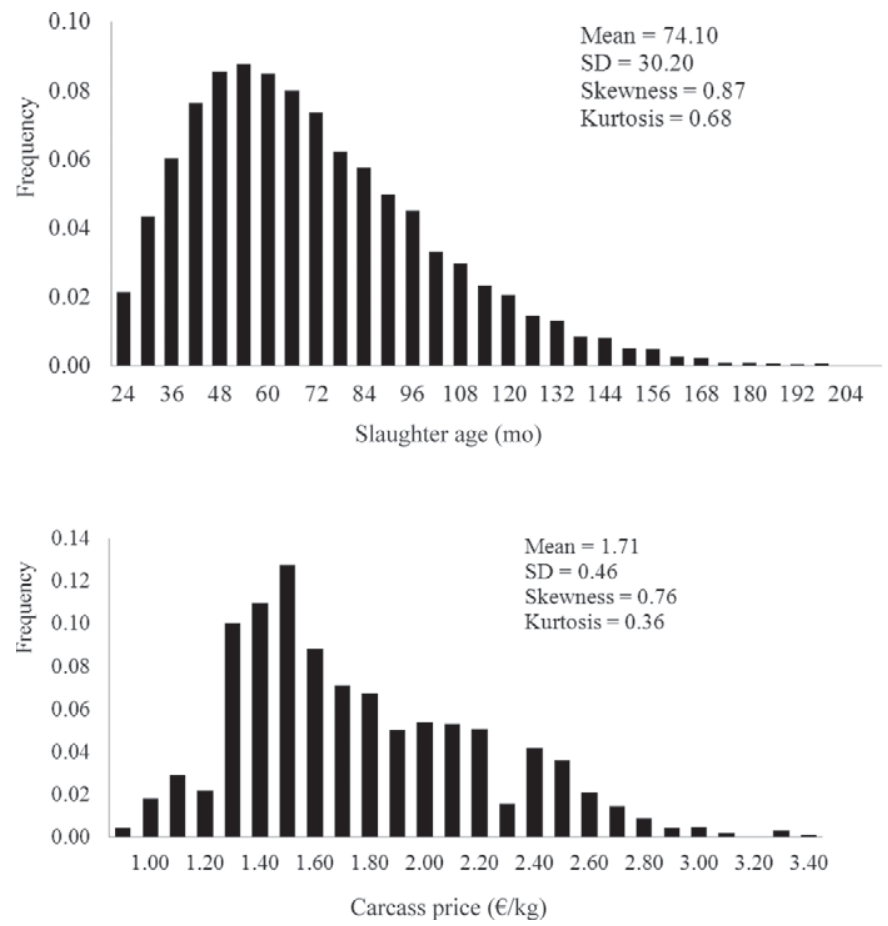

BAZZOLI ET AL.
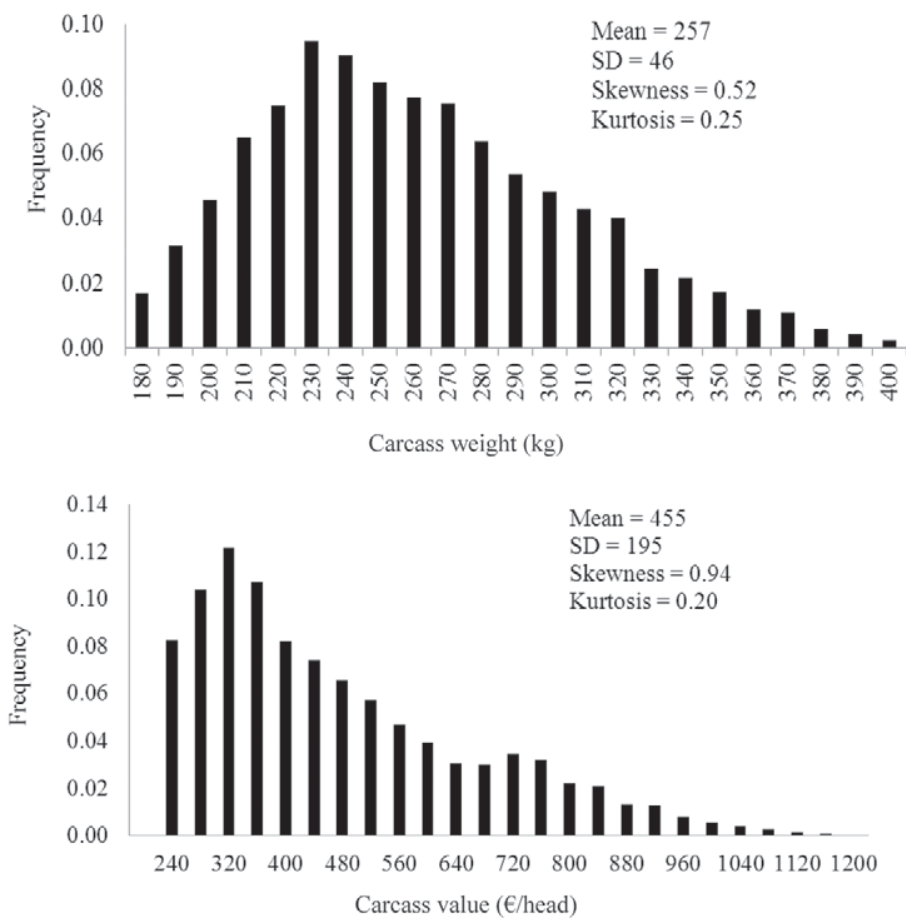

Figure 1. Frequency distribution, mean, standard deviation (SD), skewness, and kurtosis for slaughter age (mo), carcass weight (kg), carcass price $(€ / \mathrm{kg})$, and carcass value $(€ /$ head $)$ of culled cows.

were analyzed using the same model but without the linear covariate of carcass weight, and, in a separate analysis, carcass value was analyzed including in a 2-way interaction between carcass weight (continuous variable) and breed to quantify how carcass value changed per kilogram of carcass weight in different breeds. Finally, age at culling (mo) was analyzed using a simplified model without carcass weight, age of cow, and its interaction with breed.

Least squares means for the fixed effects of interest were averaged across all other fixed effects in the respective models. Orthogonal contrasts were undertaken to quantify the breed effect differences between dairy breeds and dual-purpose breeds $[(\mathrm{HF}+\mathrm{BS})$ vs. $(\mathrm{Si}+$ Re $+\mathrm{AG}$ )], between the 2 dairy breeds (HF vs. BS), between $\mathrm{Si}$ and the local dual-purpose breeds [Si vs. $(\operatorname{Re}+\mathrm{AG})]$, and between the 2 local dual-purpose breeds (Re vs. AG).

The correlation between age at slaughter, carcass weight, carcass price, and carcass value were calculated using the Spearman correlation procedure (SAS Institute, 2008) to determine potential relationships that may exist between the studied traits.

\section{RESULTS}

The frequency distribution of age at slaughter, carcass weight, carcass price, and carcass value is shown in Figure 1. Cows were slaughtered, on average, at 74 mo of age (i.e., $>6$ yr of age) with an average carcass weight, price, and value of $257 \mathrm{~kg}, 1.71 € / \mathrm{kg}$, and 455 $€ /$ head, respectively. All distributions were skewed and, in the case of price and value of the carcass, were also bimodal.

Results from the statistical analysis of slaughter traits are summarized in Table 1. The herd effect represented 6.3 to $19.8 \%$ of the variance of the traits assessed (Table 1). All of the main fixed effects included in the model were strongly associated $(P<0.0001)$ with each dependent variable except for the association between age at slaughter with year $(P=0.02)$ and month of slaughter and between carcass weight with year of slaughter $(P=$ $0.13)$. The interaction breed $\times$ month was not associated $(P=0.40)$ with carcass weight.

Spearman rank correlations between traits suggested a strong positive correlation between carcass weight and price $(0.77 ; P<0.001)$ and, as expected, between carcass value and its constituent traits carcass weight $(0.91 ; P<0.001)$ and price $(0.96 ; P<0.001)$. Near-zero correlations existed between slaughter age and carcass price $(0.06 ; P<0.001)$ and value $(0.02 ; P<0.01)$.

\section{Year and Month of Slaughter}

Carcass weight, price per kilogram, and total carcass value varied across the months of the year (Figure 2). 
Table 1. Results of ANOVA of slaughter age (mo), carcass weight $(\mathrm{kg})$, carcass price $(€ / \mathrm{kg})$, and carcass value $(€ /$ head) of 20,995 culled cows

\begin{tabular}{|c|c|c|c|c|c|c|c|c|c|}
\hline Effect $^{1}$ & df & \multicolumn{2}{|c|}{ Slaughter age } & \multicolumn{2}{|c|}{ Carcass weight } & \multicolumn{2}{|c|}{ Carcass price } & \multicolumn{2}{|c|}{ Carcass value } \\
\hline Breed (B) & 4 & 55.68 & $<0.0001$ & 57.90 & $<0.0001$ & 304.32 & $<0.0001$ & 88.57 & $<0.0001$ \\
\hline Year of slaughter $(\mathrm{Y})$ & 8 & 2.21 & 0.02 & 1.05 & 0.40 & 451.84 & $<0.0001$ & 43.07 & $<0.0001$ \\
\hline Month of slaughter (M) & 11 & 1.49 & 0.13 & 4.86 & $<0.0001$ & 13.45 & $<0.0001$ & 4.38 & $<0.0001$ \\
\hline Carcass weight $(\mathrm{CW})$ & 1 & - & - & - & - & $57,049.10$ & $<0.0001$ & - & - \\
\hline $\mathrm{Y} \times \mathrm{M}$ & 88 & 1.28 & 0.04 & 2.17 & $<0.0001$ & 25.03 & $<0.0001$ & 3.66 & $<0.0001$ \\
\hline Herd effect & 485 & \multirow{2}{*}{\multicolumn{2}{|c|}{0.140}} & \multicolumn{2}{|c|}{0.198} & \multicolumn{2}{|c|}{0.063} & \multicolumn{2}{|c|}{0.180} \\
\hline $\mathrm{RMSE}^{2}$ & - & & & \multicolumn{2}{|c|}{40.40} & \multicolumn{2}{|c|}{0.20} & \multicolumn{2}{|c|}{170} \\
\hline
\end{tabular}

${ }^{1}$ The regression coefficient of carcass price on $\mathrm{CW}$ was $+0.00797 \pm 0.00003 € / \mathrm{kg}$; herd effect expressed as proportion of variance explained by herd was calculated by dividing the corresponding component of variance by the total variance.

${ }^{2} \mathrm{RMSE}=$ root mean square error.

However, carcass weight varied $( \pm 2.5 \%)$ to a lesser extent across the months of the year than either carcass price $( \pm 4.9 \%)$ or value $( \pm 5.3 \%)$. Cows slaughtered during winter had the heaviest carcass weight, whereas those slaughtered in September were lightest. Price per kilogram exhibited an almost opposite annual trend to carcass weight, with the trend in carcass value being intermediate.

Variation in carcass weight across years was small, ranging from 250 to $253 \mathrm{~kg}$ in 2003 and 2011, respectively. The annual pattern in both carcass price and value was much more evident, increasing from 2003 to 2011 by $38.8 \%$ (from 1.52 to $2.11 € / \mathrm{kg}$ ) and $46.8 \%$ (from 374 to $549 € /$ head), respectively (Figure 3). However, the association between month of slaughter and carcass weight, value, and price differed by year of slaughter (Table 1).

\section{Breed of Cow}

The majority $(88 \%)$ of the data in the present study originated from cows of the 2 dairy breeds (HF and $\mathrm{BS}$ ); the remaining cows were from dual-purpose breeds ( $\mathrm{Si}, \mathrm{Re}$, and AG). Breed was the most strongly associated $(P<0.001)$ factor for all traits analyzed.

The dairy breeds were younger at slaughter, had lighter carcasses, and received the lowest price (at a constant carcass weight) and value than dual-purpose breeds (Table 2). Within the dairy breeds, HF was inferior to BS for all traits considered (i.e., HF cows, on average, were younger, lighter, and received lower carcass price per $\mathrm{kg}$ and total value than BS cows).

Among the dual-purpose breeds, Si cows, on average, yielded heavier carcasses, whereas the cows of the local breeds were characterized by older age at slaughter and by a higher price per kilogram of carcass. We observed no difference in carcass value between $\mathrm{Si}$ and the local

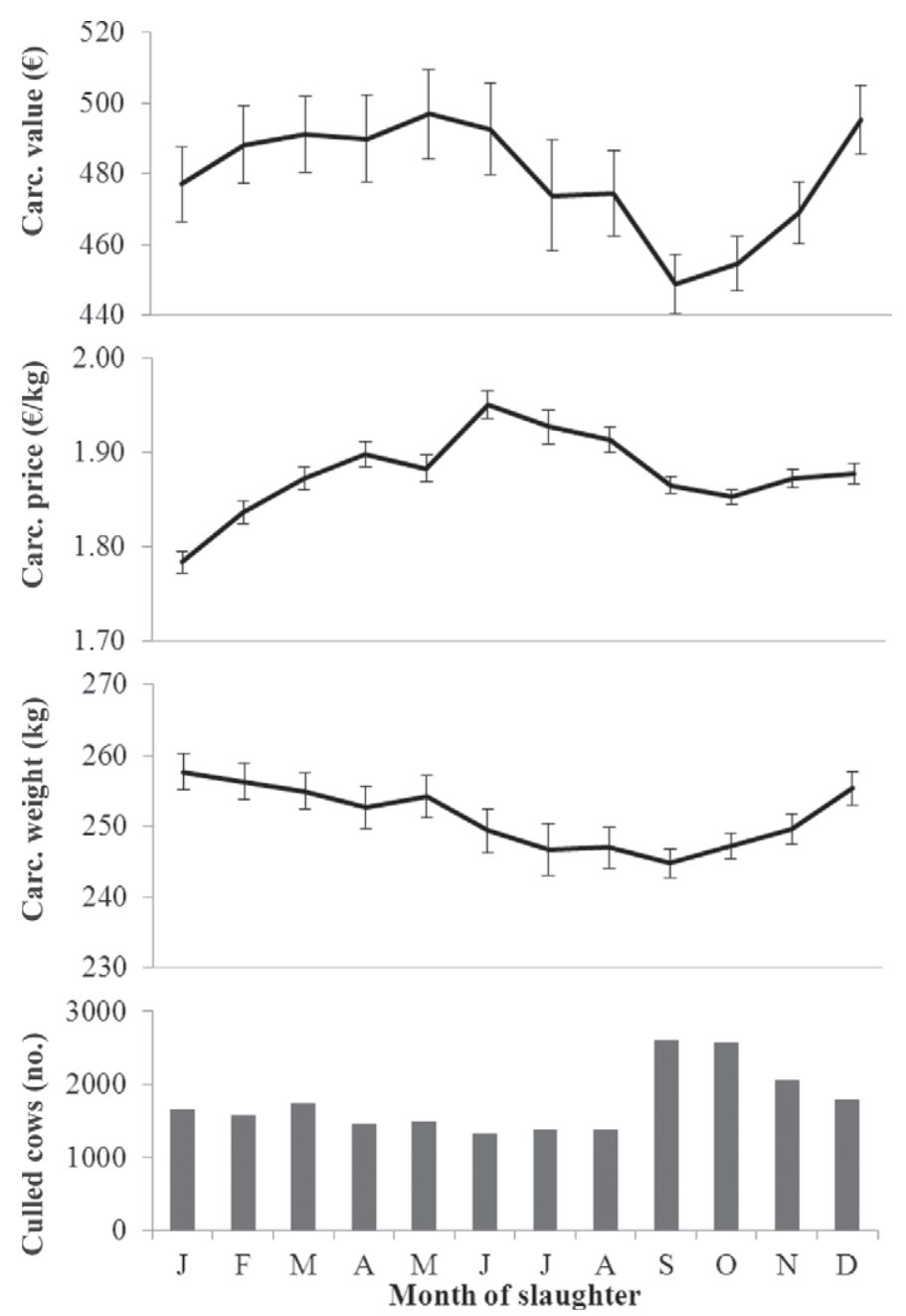

Figure 2. Monthly least squares means (1 SE represented each side of the mean as an error bar) for carcass value $(€ /$ head), carcass price $(€ / \mathrm{kg})$, carcass weight $(\mathrm{kg})$, and number of culled cows. 
1086

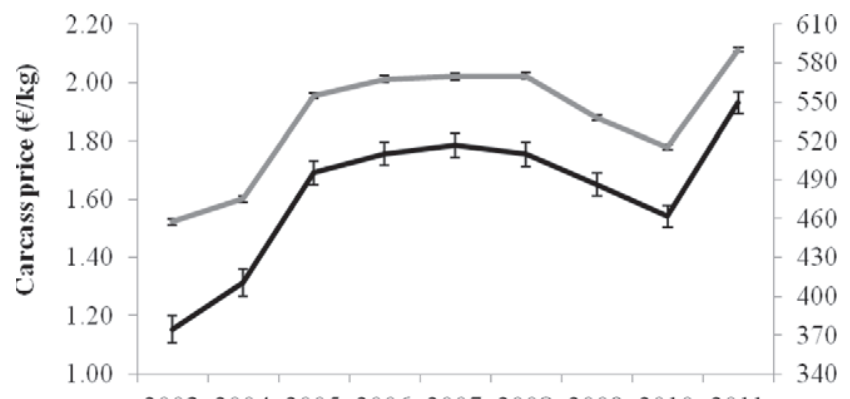

200320042005200620072008200920102011

Year of slaughter

Figure 3. Annual least squares means (SE represented as error bar) for carcass price $(€ / \mathrm{kg}$; gray line) and carcass value $(€ / \mathrm{head}$; black line) of culled cows.

dual-purpose breeds (Table 2). Of the local breeds, AG were oldest at culling and received the greatest carcass price.

The association between breed with the slaughter traits differed significantly by year of slaughter (Table 1). Age at slaughter decreased from 2003 to 2011 and was more marked for dairy breeds $(-5.7$ and -7.3 mo for HF and BS cows, respectively) than for dualpurpose breeds $(-2.1,-0.7$, and -2.0 mo for $\mathrm{Si}, \mathrm{Re}$, and AG, respectively). Additionally, the association between breed and carcass weight differed by year (Table $1)$; variation in carcass weight of the $\mathrm{BS}, \mathrm{HF}, \mathrm{AG}$, and Re breeds across years was limited, whereas that of $\mathrm{Si}$ increased by $18 \mathrm{~kg}$ from 2003 to 2011 .

The difference in carcass price between breeds varied across time (Table 1); carcass price increased more for $\mathrm{HF}$ and BS cull cows (0.67 and $0.65 € / \mathrm{kg}$, respectively) and less for the dual-purpose breeds $(0.58,0.49$, and $0.57 € / \mathrm{kg}$ for $\mathrm{Si}, \mathrm{Re}$, and $\mathrm{AG}$, respectively). The in- crease in carcass value across years (from 2003 to 2011) was very similar for the 2 dairy breeds and for AG (164, 164 , and $176 €$ /head for HF, BS, and AG, respectively), whereas it was greatest for $\mathrm{Si}$ and least for Re (237 and $135 € /$ head, respectively).

Carcass price per kilogram was highly dependent on carcass weight, as demonstrated by the regression coefficient (Table 1); as a consequence, the increase in carcass value with increasing carcass weight was greater than the average carcass price and varied across breeds (Figure 4).

\section{Age at Slaughter}

Young cull cows ( $<3$ yr old) had lighter carcasses $(236 \mathrm{~kg})$ but received the greatest carcass price $(€ 2.19$ / $\mathrm{kg}$ ) and a high value (€502/head; Table 3). Carcass weight increased with age at slaughter until 5 to $6 \mathrm{yr}$ (Table 3). Carcass price of cows slaughtered after 3 yr remained relatively constant, whereas carcass value tended to increase up to 5 to $6 \mathrm{yr}$ of age, after which the value decreased.

\section{DISCUSSION}

\section{Dairy Farming in the Alps}

Different dairy production systems exist in the Alps, varying from very traditional to the more intensive (Sturaro et al., 2009, 2013; Cocca et al., 2012). The typical traditional mountain farm is based on a small number of cows from the Alpine breeds, such as the Brown breeds, Red and White Simmental-derived breeds, and local breeds (Bittante, 2011). From autumn to late spring, cows are kept tied in the barn of the main farm

Table 2. Least squares means (LSM), SE, and contrasts of breed effect for slaughter age (mo), carcass weight (kg), carcass price (€/kg), and carcass value $(€ /$ head $)$ of culled cows

\begin{tabular}{|c|c|c|c|c|c|c|c|c|c|}
\hline \multirow[b]{2}{*}{ Breed } & \multirow[b]{2}{*}{ No. } & \multicolumn{2}{|c|}{ Slaughter age } & \multicolumn{2}{|c|}{ Carcass weight } & \multicolumn{2}{|c|}{ Carcass price } & \multicolumn{2}{|c|}{ Carcass value } \\
\hline & & LSM & $\mathrm{SE}$ & LSM & $\mathrm{SE}$ & LSM & $\mathrm{SE}$ & LSM & $\mathrm{SE}$ \\
\hline Holstein-Friesian (HF) & 8,927 & 73.1 & 0.70 & 242 & 1.2 & 1.69 & 0.004 & 394 & 4.8 \\
\hline Brown Swiss (BS) & 9,555 & 80.7 & 0.63 & 246 & 1.1 & 1.73 & 0.004 & 417 & 4.4 \\
\hline Simmental (Si) & 1,117 & 79.7 & 1.16 & 271 & 1.9 & 1.74 & 0.008 & 521 & 8.1 \\
\hline Rendena (Re) & 917 & 84.7 & 1.78 & 249 & 3.0 & 2.05 & 0.013 & 516 & 12.6 \\
\hline Alpine Grey (AG) & 479 & 93.3 & 2.31 & 249 & 4.7 & 2.18 & 0.022 & 549 & 19.7 \\
\hline \multicolumn{10}{|l|}{ Contrast ( $P$-value $)$} \\
\hline${ }^{1}(\mathrm{HF}+\mathrm{BS})$ vs. $(\mathrm{Si}+\mathrm{Re}+\mathrm{AG})$ & & \multicolumn{2}{|c|}{$* * *$} & \multicolumn{2}{|c|}{$* * *$} & \multicolumn{2}{|c|}{$* * *$} & \multicolumn{2}{|c|}{$* * *$} \\
\hline${ }^{2} \mathrm{HF}$ vs. $\mathrm{BS}$ & & \multicolumn{2}{|c|}{$* * *$} & \multicolumn{2}{|c|}{$* * *$} & \multicolumn{2}{|c|}{$* * *$} & \multicolumn{2}{|c|}{$* * *$} \\
\hline${ }^{3} \mathrm{Si}$ vs. $(\mathrm{Re}+\mathrm{AG})$ & & \multicolumn{2}{|c|}{$* * *$} & \multicolumn{2}{|c|}{$* * *$} & \multicolumn{2}{|c|}{$* * *$} & \multicolumn{2}{|c|}{ NS } \\
\hline${ }^{4}$ Re vs. AG & & \multicolumn{2}{|c|}{$* *$} & \multicolumn{2}{|c|}{ NS } & \multicolumn{2}{|c|}{$* * *$} & \multicolumn{2}{|c|}{ NS } \\
\hline
\end{tabular}

\footnotetext{
${ }^{1}(\mathrm{HF}+\mathrm{BS})$ vs. $(\mathrm{Si}+\mathrm{Re}+\mathrm{AG})=$ contrast between dairy and dual-purpose breeds.

${ }^{2} \mathrm{HF}$ vs. BS $=$ contrast between the dairy breeds.

${ }^{3} \mathrm{Si}$ vs. $(\mathrm{Re}+\mathrm{AG})=$ contrast between Simmental and the local dual-purpose breeds.

${ }^{4}$ Re vs. AG $=$ contrast between the local dual-purpose breeds.

${ }^{* *} P<0.01 ; * * P<0.001$
} 


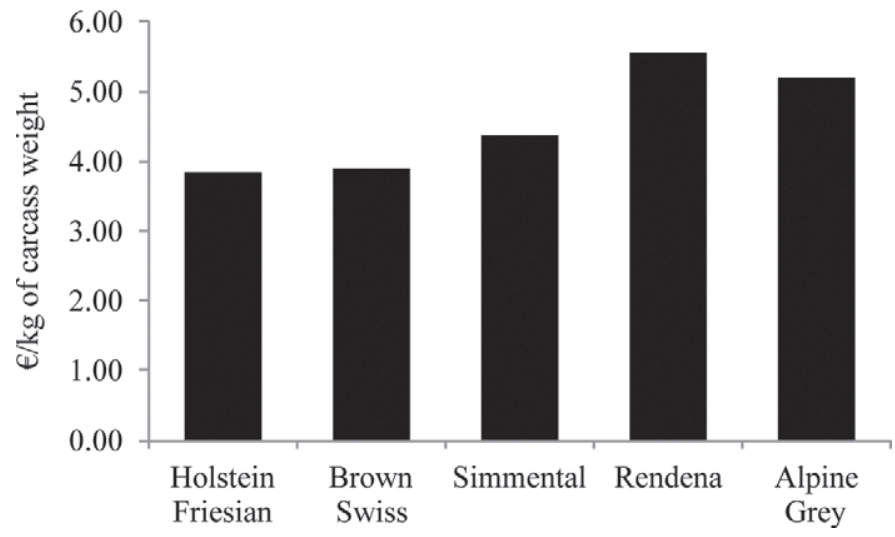

Figure 4. Within-breed regression coefficients of carcass value on carcass weight (CW; $P<0.0001 ; \mathrm{SE}$ of estimates vary from $0.01 € /$ $\mathrm{kg}$ of $\mathrm{CW}$ for Holstein-Friesian to $0.07 € / \mathrm{kg}$ of $\mathrm{CW}$ for Alpine Grey).

in the valleys, and feeding is based on hay and some concentrate, with limited access to pasture (Sturaro et al., 2009). During the summer, cows and replacement heifers are transported to the Alpine highland pastures for summer transhumance, at about 1,500 to $2,200 \mathrm{~m}$ above sea level. Alpine summer highland pastures are often the property of local communities, and animals from several farms graze together. Traditional stone and wooden buildings are used to house the animals overnight. Milk is processed locally for the production of "Malga" typical cheeses. The traditional dairy systems of the Alps are based on seasonality, with calving concentrated in the autumn and concentrated mating during the winter, so that the majority of cows are in late lactation when moved to the highlands. Barren cows identified after returning to the valley's main farm at the end of summer highland pasture are generally culled.

Traditional dairy farms in the Alpine regions are characterized by lower average milk yield than more intensive farming systems and by greater labor input per unit of milk (Sturaro et al., 2013). The traditional dairy farms partly compensate economically for this lower output by also having lower costs of production (Tiezzi et al., 2011, 2012), and especially, reduced capital costs, and external (feed) input costs. Moreover, in some areas such as Trento Province, traditional farms receive a milk price premium (20 to $40 \%$ greater; Sturaro et al., 2013) because of the superior technological properties of the milk produced (De Marchi et al., 2007; Bittante et al., 2012; Cipolat-Gotet et al., 2012) and the absence of silage and genetically modified organisms in the diet that qualify their milk for high-priced cheeses (De Marchi et al., 2008; Bittante et al., 2011a,b).

In the Alpine region, the number of traditional dairy farms is declining and they are being partly substituted by more modern and intensive farming systems based on loose rearing of cows, milking parlors, TMR, yearround calving, summer transhumance for heifers only, specialized dairy breeds (i.e., mainly HF), and higher productivity and income (Sturaro et al., 2009, 2013).

One option to partly compensate for the lower milk output in the traditional farming systems is to increase income from meat production, both as surplus calves and culled cows. Traditional mountainous dairy producers sell a higher proportion of newborn calves, because of the superior fertility and longevity of their cows, and therefore have a reduced requirement for replacement females. These surplus calves belong to breeds characterized by, on average, higher selling price and weight. Moreover, a higher proportion of cows from these herds are mated to beef bulls, often Belgian Blue sires, for the production of high-priced crossbred calves (Dal Zotto et al., 2009). The value of cull cows is also an important revenue source and the effect of different breeds on cull cow price is, to date, not well documented.

\section{Age at Slaughter of Culled Cows}

The average age of cows in the Trento Province at culling (74 mo, Figure 1) was greater than that in more intensive dairy areas (Ahlman et al., 2011; Hultgren et al., 2011; Sasaki et al., 2012). Age at culling, however, had a high coefficient of variability (41\%, Figure 1). The most important sources of variation were herd and breed of the cow.

Table 3. Least squares means (LSM) and SE of carcass weight $(\mathrm{kg})$, carcass price $(€ / \mathrm{kg})$, and carcass value $(€ /$ head $)$ of cull cows at different age at slaughter

\begin{tabular}{|c|c|c|c|c|c|c|c|}
\hline \multirow{2}{*}{$\begin{array}{l}\text { Slaughter } \\
\text { age (yr) }\end{array}$} & \multirow[b]{2}{*}{ No. } & \multicolumn{2}{|c|}{ Carcass weight } & \multicolumn{2}{|c|}{ Carcass price } & \multicolumn{2}{|c|}{ Carcass value } \\
\hline & & LSM & $\mathrm{SE}$ & LSM & $\mathrm{SE}$ & LSM & SE \\
\hline$<3$ & 1,363 & 236 & 4.43 & 2.19 & 0.02 & 502 & 18.61 \\
\hline $3-4$ & 2,871 & 245 & 2.29 & 1.85 & 0.01 & 446 & 9.53 \\
\hline $4-5$ & 3,639 & 253 & 2.11 & 1.81 & 0.01 & 470 & 8.77 \\
\hline 5-6 & 3,465 & 261 & 1.94 & 1.82 & 0.01 & 504 & 8.07 \\
\hline $6-7$ & 2,857 & 257 & 1.88 & 1.81 & 0.01 & 481 & 7.79 \\
\hline$>7$ & 6,800 & 257 & 1.43 & 1.78 & 0.01 & 473 & 5.84 \\
\hline
\end{tabular}


Even if the average age at slaughter of cull cows in the Trento Province was greater than the longevity of the cows enrolled in the national herdbooks, the differences among the dairy and dual-purpose breeds of the Alpine province reflect the differences in longevity documented at the national level. Differences in longevity of cows are influenced by both genetic and environmental factors. The international breeding goals of dairy breeds has broadened to include fertility, longevity, and correlated type traits (Miglior et al., 2005) to halt or reverse the decline in functional longevity observed in dairy cattle. Comparing the longevity of HF, BS, and Jersey cows in alternative regions of the United States, Garcia-Peniche et al. (2006) obtained different results when the breeds were compared using data from single-breed herds and mixed-breed herds. Moreover, Garcia-Peniche et al. (2006) documented similar overall longevity for HF and BS cows but reported a highly significant interaction between breed and region, concluding that an important component of the differences among breeds were differences among the production systems and environments. Vukasinovic et al. (2001), studying BS, Si, and HF cows in Switzerland, found that the risk of culling was much lower for cows moved to summer Alpine pastures than for cows in the lowland barns year round. This may be a contributing factor to the different age at slaughter of dairy and dual-purpose breeds in the present study, given that the latter are more represented in traditional farms practicing summer transhumance, whereas the former are more represented in the more intensive farms (Sturaro et al., 2009, 2013). In the Irish pasture system, dual-purpose breeds had superior longevity to Holsteins (Evans et al., 2004).

The more rapid decrease in age at slaughter from 2003 to 2011 in HF and BS cows but not in the dual-purpose breeds (interaction between breed and year effects) can be explained more by environmental than genetic reasons. In fact, the tendency toward the abandonment of the traditional farming system and the increase of modern intensive farms affected, in particular, the 2 specialized dairy breeds (Giupponi et al., 2006; Sturaro et al., 2013).

\section{Carcass Weight of Culled Cows}

Carcass weight of cull cows was heaviest during winter and lightest during autumn (Figure 2), concomitant with the return from summer pastures and the end of lactation in the more traditional farming systems. Culling rate in September and October was almost double that in June, July, and August (the months of the summer pasture). McHugh et al. (2010) observed that in Ireland the number of cows sold at market exhibited a bimodal distribution, with greater numbers sold in spring (postpartum period) and autumn (end of lactation). It should be noted that, in that case, only a proportion of the cows sold at markets were slaughtered within a few days and these data referred to both dairy and beef cows. Considering only slaughtered animals in Ireland, Maher et al. (2008) found that the greatest number of cows were culled in October and November, 1 mo later than in the present study, although the grazing season is expected to be longer in Ireland than in the Alpine highland regions.

Average carcass weight of the HF cull cows in the present study was greater than that documented for the same breed by Yan et al. (2009) in lactating cows, but was similar to that reported by Vestergaard et al. (2007) and by Minchin et al. (2009) for dry cows slaughtered without a fattening period, and less than that documented by Seegers et al. (1998), Jurie et al. (2007), and Węglarz (2011) for cows subjected to an extra feeding period. Heavier liveweight and carcass weight is expected when cull cows are subjected to a finishing period, as confirmed by several studies (Allen et al., 2009; Franco et al., 2009; Minchin et al., 2009). No detailed information is available on the feeding regimen of cull cows by farmers in Trento Province but, except for cows slaughtered with urgency (e.g., due to calving problems, severe mastitis, accidents, lameness), cows are normally slaughtered toward the end of lactation when the marginal profit of milk production per day becomes negative.

Compared with the number of studies on HF cull cows, little information exists on cull cows from other dairy breeds. Often when comparisons do exist, the different dairy breeds are simply grouped as "dairy cows" whereas data on dual-purpose breeds generally originate from beef herds. Whether the slightly heavier carcass weight for BS cows compared with HF in the present study was due to a greater liveweight or a superior dressing percentage is not known. It is worth noting, however, that the least squares means in Table 2 were obtained from a model that included age at slaughter; considering the younger age at culling of $\mathrm{HF}$ cows and the increase of carcass weight with age, larger differences between actual breed averages are expected.

The dual-purpose Alpine breeds had heavier carcasses than cows from specialized dairy breeds, with Si cows yielding the heaviest average carcass weight; this was consistent with results documented by Habermann et al. (2000) on Simmental cows slaughtered after drying off without any finishing period. Habermann et al. (2000) found that, after $98 \mathrm{~d}$ of finishing, average liveweight increased $147 \mathrm{~kg}$ and carcass weight $104 \mathrm{~kg}$, confirming a high finishing weight gain, which characterizes the Simmental breed. 
The Re and AG local breeds are known as mediumframed, dual-purpose breeds with lesser average liveweight than HF and BS cows. The heavier carcass of the local breeds in the present study is therefore most likely due to a greater dressing percentage. Greater dressing percentage is also the result of a breeding program that included, in the case of Re, a combined index of growth capacity, in vivo estimated dressing percentage, and carcass muscularity (Bittante et al., 2007). Comparisons carried out on fattening young bulls of the 3 dual-purpose breeds confirmed the superiority of Si breed in terms of body size and weight gain, but also the good dressing percentage and meat quality of both local Alpine breeds (Bonsembiante et al., 1988; Cozzi et al., 2009).

\section{Carcass Price and Value of Culled Cows}

Few studies have quantified the factors associated with cull cow market value. Differences in yield and value of individual retail cuts of $\mathrm{HF}$ and $\mathrm{Si}$ cow carcasses were studied by Kaufmann et al. (1996). The carcasses of young Si females in the study of Kaufmann et al. (1996) were $21.9 \%$ more valuable than those of $\mathrm{HF}$ cows but this difference in value was reduced to $8.5 \%$ in older cows; in the present study, the difference in carcass values was 33.1 and $24.2 \%$ in young and older cows, respectively. In our study, the association between cow breed and both carcass price and value also differed by age of cow at slaughter, confirming that the superiority of dual-purpose cows was greatest when they were younger.

More recently, McHugh et al. (2010), analyzing the value of cows sold at auctions in Ireland, reported that $\mathrm{Si}$ received a $20.3 \%$ price premium compared with $\mathrm{HF}$ without correcting for liveweight; this reduced to $15.2 \%$ after adjustment for differences in liveweight. In the study of McHugh et al. (2010), however, the data were obtained on live animals, only some of which were slaughtered within a few days of purchase. Moreover, Si cows in Ireland generally reside in beef herds as suckler cows and are generally not used for milk production, thus influencing the results. McHugh et al. (2010) also reported that the dual-purpose breeds of Montbéliarde and Normande were worth 9.9 and $16.6 \%$ more, respectively, than Holstein; when liveweight was included in the model, the respective values were 14.1 and $16.8 \%$. Dal Zotto et al. (2009), analyzing the auction price of Italian calves produced by 4 of the 5 breeds considered in the present study in the same environment, reported greater prices for Si calves, followed by AG, and subsequently by the 2 dairy breeds (HF and BS).

McHugh et al. (2011) reported that the value of beef and dairy cows sold at auction was heritable, even though the heritability of animal value was approximately half that of liveweight and much lower than heritability estimates for animal value of calves, weanlings and postweanlings. Penasa et al. (2012) found, using BS calves sold at auction and produced in the same environment as in the present study, that animal value is heritable, as is body weight. Moreover, other studies (Otto et al., 1991; Gregory et al., 1998; Minchin et al. 2009) documented the positive effect of cow body condition on quantity and quality traits of the cull cow at slaughter. Body condition score of dairy cows is heritable (Gallo et al., 2001) and selection for increased BCS improves cow fertility (Berry et al., 2003; Dal Zotto et al., 2007); this indirect selection could increase the value of cull cows.

It is interesting to note that the increase in carcass value, within breed, per unit increase in carcass weight was much greater (2 to 2.5 times) than that of the average price per kilogram of carcass (Figure 4). This implies a greater emphasis by the purchaser on quality than on quantity (i.e., carcass weight). Several studies demonstrated that fattening of cull cows increased not only liveweight but also dressing percentage, the muscularity and fatness of carcasses, the incidence of superior retail cuts, and quality attributes (Habermann et al., 2000; Vestergaard et al., 2007; Allen et al., 2009; Franco et al., 2009). None of these studies attempted to quantify the increase in price and value due to fattening of cull cows.

\section{CONCLUSIONS}

The value of cull cows at slaughter represents a source of income for dairy farms. However, considerable variation in cull cow value exists. The main sources of variation were breed, herd, age, and weight of carcass, as well as year and season of slaughter. HolsteinFriesian cows were younger at slaughter, yielded lighter carcasses, and received a lower price and total value compared with Brown Swiss cows. Dual-purpose breeds were older and heavier and received a greater price and value at slaughter than either dairy breed. Thus, in traditional small Alpine farms, the value of dual-purpose cull cows, combined with better longevity, fertility, value of purebred calves, lower feed inputs, and better milk quality, can partially compensate for the lower milk production yields of dual-purpose cows relative to specialized dairy breeds. Of the dual-purpose cows, Simmental cows were heaviest, whereas Rendena and Alpine Grey cows received the greater price, resulting in no difference in carcass value among the dualpurpose breeds. The large differences among different breeds in cull cow value highlight the importance of cull cow characteristics, especially in traditional moun- 
tain dairy systems characterized by limited milk productivity. This suggests the possibility to include such traits in the breeding objectives of these breeds, but underlines the need for better comprehension of the interactions between breed of cow and the alternative dairy production systems of mountainous areas, moving from traditional to modern dairy farms. Moreover, the quantification of the combined effect of weight and price on the increase in value of the carcass highlights the possible economic advantage of fattening culled cow before slaughtering.

\section{ACKNOWLEDGMENTS}

The authors thank the Trento Province (Italy) for financial support and the Breeders Federation of Trento (Italy) and Unipeg Cooperative (Pegognaga, Mantova, Italy) for providing the data.

\section{REFERENCES}

Agresti, A. 2002. Building and applying logistic regression models Pages 216-217 in Categorical Data Analysis. John Wiley \& Sons Inc., Hoboken, NJ.

Ahlman, T., B. Berglund, L. Rydhmer, and E. Strandberg. 2011. Culling reasons in organic and conventional dairy herds and genotype by environment interaction for longevity. J. Dairy Sci. 94:1568 1575 .

Akaike, H. 1969. Fitting autoregressive models for prediction. Ann. Inst. Stat. Math. 21:243-247.

Allaire, F. R., H. E. Sterwerf, and T. M. Ludwick. 1976. Variations in removal reasons and culling rates with age for dairy females. J. Dairy Sci. 60:254-267.

Allen, J. D., J. K. Ahola, M. Chahine, J. I. Szasz, C. W. Hunt, C. S. Schneider, G. K. Murdoch, and R. A. Hill. 2009. Effect of preslaughter feeding and ractopamine hydrochloride supplementation on growth performance, carcass characteristics, and end product quality in market dairy cows. J. Anim. Sci. 87:2400-2408.

Apple, J. K. 1999. Influence of body condition score on live and carcass value of cull beef cows. J. Anim. Sci. 77:2610-2620.

Bascom, S. S., and A. J. Young. 1998. A summary of the reasons why farmers cull cows. J. Dairy Sci. 81:2299-2305.

Beaudeau, F., A. Hemken, C. Fourichon, K. Frankena, and H. Seegers. 1993. Associations between health disorders and culling of dairy cows: A review. Livest. Prod. Sci. 35:213-236.

Berry, D. P., F. Buckley, P. Dillon, R. D. Evans, M. Rath, and R. F. Veerkamp. 2003. Genetic relationships among body condition score, body weight, milk yield, and fertility in dairy cows. J. Dairy Sci. 86:2193-2204.

Bittante, G. 2011. Italian animal genetic resources in the Domestic Animal Diversity Information System of FAO. Ital. J. Anim. Sci. 10:151-158.

Bittante, G., I. Andrighetto, and M. Ramanzin. 2007. Fondamenti di Zootecnica. Liviana Scolastica, Italy.

Bittante, G., A. Cecchinato, N. Cologna, M. Penasa, F. Tiezzi, and M. De Marchi. 2011a. Factors affecting the incidence of first-quality wheels of Trentingrana cheese. J. Dairy Sci. 94:3700-3707.

Bittante, G., N. Cologna, A. Cecchinato, M. De Marchi, M. Penasa, F. Tiezzi, I. Endrizzi, and F. Gasperi. 2011b. Monitoring of sensory attributes used in the quality payment system of Trentingrana cheese. J. Dairy Sci. 94:5699-5709.

Bittante, G., M. Penasa, and A. Cecchinato. 2012. Invited review: Genetics and modeling of milk coagulation properties. J. Dairy Sci. 95:6843-6870.
Bonsembiante, M., I. Andrighetto, G. Bittante, G. Cozzi, and M. Spanghero. 1988. Beef production from young bulls of two dairy and four dual purpose breeds. Zootecn. Nutr. Anim. 14:325-340.

Brown, W. F., and D. D. Johnson. 1991. Effects of energy and protein supplementation of ammoniated tropical grass hay on the growth and carcass characteristics of cull cows. J. Anim. Sci. 69:348-357.

Cabaraux, J.-F., I. Dufrasne, M. Roux, L. Istasse, and J. L. Hornick. 2005. La production de viande bovine à partir de femelles de réforme. INRA Prod. Anim. 18:37-48.

Cesarini, F., E. Sturaro, B. Contiero, G. Bittante, and L. Gallo. 2003 Effects of health disorders on milk yield and calving interval in Italian Holstein cows. Ital. J. Anim. Sci. 2(Suppl. 1):160-162.

Cipolat-Gotet, C., A. Cecchinato, M. De Marchi, M. Penasa, and G. Bittante. 2012. Comparison between mechanical and near-infrared methods for assessing coagulation properties of bovine milk. J. Dairy Sci. 95:6806-6819.

Cocca, G., E. Sturaro, L. Gallo, and M. Ramanzin. 2012. Is the abandonment of traditional livestock farming systems the main driver of mountain landscape change in Alpine areas? Land Use Policy $29: 878-886$.

Cozzi, G., M. Brscic, B. Contiero, and F. Gottardo. 2009. Growth, slaughter performance and feeding behaviour of young bulls belonging to three native cattle breeds raised in the Alps. Livest. Sci. 125:308-313.

Dal Zotto, R., M. De Marchi, C. Dalvit, M. Cassandro, L. Gallo, P. Carnier, and G. Bittante. 2007. Heritabilities and genetic correlation of body condition score and calving interval with yield, somatic cell score, and linear type traits in Brown Swiss cattle. J. Dairy Sci. 90:5737-5743.

Dal Zotto, R., M. Penasa, M. De Marchi, M. Cassandro, N. Lòpez-Villalobos, and G. Bittante. 2009. Use of crossbreeding with beef bulls in dairy herds: Effect on age, body weight, price, and market value of calves sold at livestock auctions. J. Anim. Sci. 87:3053-3059.

De Boer, H. 1980. Cow beef production in the Netherlands: Perspective for improvements. Pages 56-64 in The Cull Cow as a Beef Producer. Proc. C.E.C. Seminar, Rome, Italy. D. M. Allen and A. Romita, ed.

De Marchi, M., G. Bittante, R. Dal Zotto, C. Dalvit, and M. Cassandro. 2008. Effect of Holstein Friesian and Brown Swiss breeds on quality of milk and cheese. J. Dairy Sci. 91:4092-4102.

De Marchi, M., R. Dal Zotto, M. Cassandro, and G. Bittante. 2007. Milk coagulation ability of five dairy cattle breeds. J. Dairy Sci 90:3986-3992.

Dransfield, E., I. F. Martin, D. Bauchart, S. Abouelkaram, J. Lepetit, J. Culioli, C. Jurie, and B. Picard. 2003. Meat quality and composition of three muscles from French cull cows and young bulls. Anim. Sci. 76:387-399.

Esslemont, R. J., and M. A. Kossaibati. 1997. Culling in 50 dairy herds in England. Vet. Rec. 140:36-39.

Evans, R. D., P. Dillon, L. Shalloo, M. Wallace, and D. J. Garrick. 2004. An economic comparison of dual-purpose and Holstein-Friesian cow breeds in a seasonal grass-based treatment under different milk production scenarios. Ir. J. Agric. Food Res. 43:1-16.

Franco, D., E. Bispo, L. Gonzalez, J. A. Vazquez, and T. Moreno. 2009. Effect of finishing and ageing time on quality attributes of loin from the meat of Holstein-Friesian cull cows. Meat Sci. 83:484-491.

Gallo, L., P. Carnier, M. Cassandro, R. Dal Zotto, and G. Bittante. 2001. Test-day genetic analysis of condition score and heart girth in Holstein Friesian cows. J. Dairy Sci. 84:2321-2326.

Garcia-Peniche, T. B., B. G. Cassell, and I. Misztal. 2006. Effects of breed and region on longevity traits through five years of age in Brown Swiss, Holstein, and Jersey cows in the United States. J. Dairy Sci. 89:3672-3680.

Giupponi, C., M. Ramanzin, E. Sturaro, and S. Fuser. 2006. Climate and land use changes, biodiversity and agri-environmental measures in the Belluno Province, Italy. Environ. Sci. Policy 9:163173.

Gregory, N. G., J. K. Robins, D. G. Thomas, and R. W. Purchas. 1998. Relationship between body condition score and body composition in dairy cows. N. Z. J. Agric. Res. 41:527-532. 
Habermann, W., K. Luge, J. Frickh, W. Zollitsch, and F. Lettner. 2000. Is fattening of cull cows worthwhile? Analysis of feeding regimen, meat quality and profitability. Die Bodenkultur. 51:59-69.

Heikkilä, A. M., J. I. Nousiainen, and S. Pyörälä. 2012. Cost of clinical mastitis with special reference to premature culling. J. Dairy Sci. 95:139-150.

Hultgren, J., C. Svensson, and M. Pehrsson. 2011. Rearing conditions and lifetime milk revenues in Swedish dairy cows. Livest. Sci. 137:108-115.

Jurie, C., B. Picard, J.-F. Hocquette, E. Dransfield, D. Micol, and A. Listrat. 2007. Muscle and meat quality characteristics of Holstein and Salers cull cows. Meat Sci. 77:459-466.

Kaufmann, A., H. Leuenberger, and N. Künzi. 1996. Relative carcass value of Simmental, Holstein and their crosses base on veal calves, fattening bulls and culled cows in Switzerland. Livest. Prod. Sci. $46: 13-18$.

Liboriussen, T. 1980. Beef production in Denmark. Pages 11-13 in The Cull Cow as Beef Producer. Proc. C.E.C. Seminar, Rome, Italy. D. M. Allen and A. Romita, ed.

Maher, P., M. Good, and S. J. More. 2008. Trends in cow numbers and culling rate in the Irish cattle population, 2003 to 2006 . Ir. Vet. J. 61:455-463.

Matulis, R. J., F. K. McKeith, D. B. Faulkner, L. L. Berger, and P. George. 1987. Growth and carcass characteristics of cull cows after different times-on-feed. J. Anim. Sci. 65:669-674.

Mc Hugh, N., R. D. Evans, P. R. Amer, A. G. Fahey, and D. P. Berry. 2011. Genetic parameters for cattle price and body weight from routinely collected data at livestock auctions and commercial farms. J. Anim. Sci. 89:29-39.

Mc Hugh, N., A. G. Fahey, R. D. Evans, and D. P. Berry. 2010. Factor associated with selling price of cattle at livestock marts. Animal 4:1378-1389.

Miglior, F., B. L. Muir, and B. J. Van Doormaal. 2005. Selection indices in Holstein cattle of various countries. J. Dairy Sci. 88:12551263.

Miller, M. F., H. R. Cross, J. D. Crouse, and T. G. Jenkins. 1987. Effect of feed energy intake on collagen characteristics and muscle quality of mature cows. Meat Sci. 21:287-294.

Minchin, W., F. Buckley, D. A. Kenny, M. G. Keane, L. Shalloo, and M. O'Donovan. 2009. Prediction of cull cow carcass characteristics from liveweight and body condition score measured pre slaughter. Ir. J. Agric. Food Res. 48:75-86.

Minchin, W., F. Buckley, D. A. Kenny, F. J. Monahan, L. Shallow, and M. O'Donovan. 2009. Effect of grass silage and concentrate based finishing strategies on cull dairy cow performance, carcass and meat quality characteristics. Meat Sci. 81:93-101.

Otto, K. L., J. D. Ferguson, D. G. Fox, and C. J. Sniffen. 1991. Relationship between body condition score and composition of ninth to eleventh rib tissue in Holstein dairy cows. J. Dairy Sci. 74:852859.

Penasa, M., A. Cecchinato, R. Dal Zotto, H. T. Blair, N. Lopez-Villalobos, and G. Bittante. 2012. Direct and maternal genetic effects for body weight and price of calves sold for veal production. J. Anim. Sci. 90:3385-3391.
SAS Institute. 2008. SAS ${ }^{\circledR}$ User's Guide. Version 9.1.3 ed. SAS Institute Inc., Cary, NC.

Sasaki, O., M. Aihara, K. Hagiya, A. Nishiura, K. Ishii, and M. Satoh. 2012. Genetic evaluation of the longevity of the Holstein population in Japan using a Weibull proportional hazard model. Anim. Sci. J. 83:95-102.

Schnell, T. D., K. E. Belk, J. D. Tatum, R. K. Miller, and G. C. Smith. 1997. Performance, carcass, and palatability traits for cull cow fed high-energy concentrate diets for $0,14,28,42$, or 56 days. J. Anim. Sci. 75:1195-1202.

Seegers, H., N. Bareille, and F. Beaudeau. 1998. Effect of parity, stage of lactation and culling reason on the commercial carcass weight of French Holstein cows. Livest. Prod. Sci. 56:79-88.

Smith, J. W., L. O. Ely, and A. M. Chapa. 2000. Effect of region, herd size and milk production on reasons cows leave the herd. J. Dairy Sci. 83:2980-2987.

Sturaro, E., G. Cocca, L. Gallo, M. Mrad, and M. Ramanzin. 2009. Livestock systems and farming styles in Eastern Italian Alps: An on-farm survey. Ital. J. Anim. Sci. 8:541-554.

Sturaro, E., E. Marchiori, M. Penasa, M. Ramanzin, and G. Bittante. 2013. Dairy systems in mountain areas in terms of farm animal biodiversity, milk production and destination and land use and landscape preservation. Livest. Sci. 10.1016/j.livsci.2013.09.011.

Tiezzi, F., C. Maltecca, A. Cecchinato, M. Penasa, and G. Bittante. 2012. Genetic parameters for fertility of dairy heifers and cows at different parities and relationships with production traits in first lactation. J. Dairy Sci. 95:7355-7362.

Tiezzi, F., C. Maltecca, M. Penasa, A. Cecchinato, and G. Bittante. 2011. Genetic analysis of fertility in the Italian Brown Swiss population using different models and trait definitions. J. Dairy Sci. 94:6162-6172.

USDA (US Department of Agriculture). 2005. Livestock slaughter-2004 summary. USDA, Natl. Agric. Stat. Serv., Washington, DC.

van Arendonk, J. A. M., P. E. Stokvisch, S. Korver, and J. K. Oldenbroek. 1984. Factors determining the carcass value of culled dairy cows. Livest. Prod. Sci. 11:391-400.

Vestergaard, M., N. T. Madsen, H. B. Bligaard, L. Bredahl, P. T. Rasmussen, and H. R. Andersen. 2007. Consequences of two or four months of finishing feeding of culled dry dairy cows on carcass characteristics and technological and sensory meat quality. Meat Sci. 76:635-643.

Vukasinovic, N., J. Moll, and L. Casanova. 2001. Implementation of a routine genetic evaluation for longevity based on survival analysis techniques in dairy cattle populations in Switzerland. J. Dairy Sci. 84:2073-2080.

Weglarz, A. 2011. Effect of pre-slaughter housing of different cattle categories on beef quality. Anim. Sci. Pap. Rep. 29:43-52.

Wiemer, E., H. O. Gravert, and K. Pabst. 1982. Bestimmungsfaktoren für den Schlachtwert gemertzer milchkühe. Züchtunsungskunde 54:186-197.

Yan, T., C. S. Mayne, D. C. Patterson, and R. E. Agnew. 2009. Prediction of body weight and empty body composition using body size measurements in lactating dairy cows. Livest. Sci. 124:233-241. 